ISVOS Journal, 2021, 5(2): 135-143 - https://doi.org/10.47897/bilmes.986237

\title{
Determining The Relationship Between Conscient Intelligence Features and Their Xenophobia Towards Refugees of The Midwifery Students
}

\author{
Ayşenur Kahraman a,1 Ayşe Çataloluk ${ }^{\mathrm{a}}$, Özgür Alparslan ${ }^{\mathrm{a}}$ \\ The Faculty of Health Sciences, Tokat Gaziosmanpaşa University, Tokat, Turkey \\ ORCID ID: 0000-0001-8194-9776 \\ ORCID ID: 0000-0002-9344-107X \\ ORCID ID: 0000-0002-2264-2886
}

\begin{abstract}
The research was conducted to determine the relationship between the xenophobic attitudes of midwifery students towards refugees and their conscientiousness. The descriptive and cross-sectional study was conducted with students studying in the midwifery department of a health sciences faculty between April 15 and May 15, 2021. The population of the study consisted of midwifery students $(\mathrm{N}=368)$, and the sample consisted of 218 students who voluntarily agreed to participate in the research. "Personal Information Form", "Conscious Intelligence Scale" and "Xenophobia Scale" were used as data collection tools. According to the xenophobia scale total scores of the students participating in the study, it was determined that xenophobia was below the moderate level and the conscientious intelligence scores were quite high. A statistically significant difference was found between the students' grades and the total scores of the xenophobia scale. As a result of the correlation analysis performed to determine the relationship between the scales, no significant relationship was found between the total scores obtained from the scales. Positive and weak $(\mathrm{r}=.144, \mathrm{p}=0.034)$ between the total score of the Xenophobia scale and the ethical values sub-dimension of the Conscientious Intelligence Scale, and weak ( $\mathrm{r}=-.191$, ) between the total score of the Xenophobia scale and the compassion sub-dimension of the Conscientious Intelligence Scale. $\mathrm{p}=0.005$ ) relationship was determined. In the study, it was determined that midwifery students' fear of refugees was below the medium level and their conscientious intelligence scores were quite high. This research will fill the gap in the field and will provide a new perspective on the approach and communication to refugees in the provision of health services.
\end{abstract}

Keywords: Midwifery, Refugee, Xenophobia, Conscientious Intelligence, Midwifery student

\section{Giriş}

Göç “insanların bir coğrafya üzerinde anlamlı bir etki yaratacak bir sürede gerçekleştirdiği yer değiştirme” ya da "bireylerin veya grupların, sosyal, ekonomik, kültürel ve siyasal nedenlerden dolayı yaşamlarını sürdürdükleri yerden, hayatlarının tamamını ya da bir kısmını geçirmek üzere başka yere yerleşmek koşuluyla yer değiştirmeleri” olarak tanımlanmaktadır (Gümüş ve Bilgili, 2015). Literatürde göç eden bireylerle ilgili bazı tanımlamalar yapılmıştır. Mülteci "ırkı, dini, milliyeti, belli bir sosyal gruba mensubiyeti veya siyasi düşünceleri nedeniyle zulüm göreceği konusunda haklı bir korku taşıyan ve bu yüzden ülkesinden ayrılan ve korkusu nedeniyle geri dönemeyen veya dönmek istemeyen kişiler” olarak tanımlanmıştır ve bu bireylere özel statü ve hukuki koruma garanti edilmiştir (Birleşmiş Milletler Mülteci Örgütü [UNHCR], 1967).

Küreselleşme ile dünya genelinde giderek artan uluslararası göç olayı, içinde bulunduğumuz çağın “göçler çağı” olarak nitelendirilmesine yol açmıştır (Miller ve Castles, 2008). İstatistikler bu durumun ulaştığı boyutların azımsanamayacak ölçüde olduğuna dikkat çekmektedir. Birleşmiş Milletler Mülteci Örgütü’nün (UNHCR) 2019 küresel eğilimler raporunda; 2019 y1lının sonuna gelindiğinde dünya genelinde 79.5 milyon insan zulüm, çatışma, şiddet, insan hakları ihlalleri veya kamu düzenini ciddi şekilde bozan olaylar sonucunda zorla göç ettikleri belirtilmektedir. Yine aynı rapora göre Türkiye, çoğu Suriyeli mülteci (\%92) olmak üzere, 3.9 milyon insanla sınır ötesi yerinden edilmiş en yüksek sayıda insana ev sahipliği yapmaktadır (UNHCR, 2019).

Mültecilerin göç olayıyla birlikte yer değiştirmeleri onları fiziksel, sosyal ve psikolojik olmak üzere pek çok açıdan etkilemektedir (UNHCR, 2019). Bu durumların yanı sıra göç eden bireyleri etkileyen bir diğer durumda henüz ev sahibi ülkeye ulaşmadan başlayan zenofobik tutumdur. Yabancı düşmanlığı ya da yabancı korkusu (Zenofobi) Yunanca bir kelime olup, literatürde "farklı ülkenin insanlarına karşı duygusal ve davranışsal olarak sergilenen önyargı" olarak tanımlanmaktadır (Yakushko, 2008). Uluslararası Çalışma Örgütü (ILO) yabancı düşmanlığını "insanları toplumda ya da ulusal kimliğe yabancı oldukları algısına dayanarak reddeden, dışlayan ve çoğu zaman suçlayıcı davranış ile önyargılar” olarak tanımlamaktadır (ILO, 2001). Yabancı düşmanlığı tutumuna maruz kalan bireyler ev sahibi ülkede kendilerini değersiz hissetmekte ve eğitim sağlik gibi temel ihtiyaçlardan yararlanma konusunda korku yaşayabilmektedirler. Mültecilere yönelik sağlık hizmetlerine erişim konusunda ev 
sahibi ülkenin sağlı personellerinin zenofobik tutumu, iletişim problemlerine ve sağlık bakımı alma konusunda engellere neden olmaktadır (Suleman et. al., 2018). Oysa sağlık alanındaki tüm meslek mensuplarının empati yapabilen, hastalara karşı hoşgörülü ve sabırlı bireyler olması gerekmektedir. Bu özelliklerin yanı sıra sağlık profesyonellerinin vicdan yetisine de sahip olması gerekmektedir. Vicdan "kişinin kendi ahlâk değerlerini dolaysız bir biçimde kendiliğinden yargılamasını sağlayan iç yeti ya da kişiyi bunu yapmaya yönelten iç duyu” olarak tanımlanmaktadır (İmamoğlu, 2010).

Vicdan konusunda literatüre Aktı ve arkadaşları tarafından (2017) yakın zamanda "vicdani zeka" kavramı kazandırılmıştır. Nitekim literatürde sağlık alanında vicdani zekâ konusunda araştırmalar mevcuttur (Urgan, 2020; Boz ve ark., 2019). Arama Kurtarma Derneği (AKUT) bünyesinde gönüllü hizmet sunan sağlık profesyonellerinin vicdani zekâ ve yaşam tatmini ile iş performansının araştırıldığı bir çalışmada vicdani zekâ düzeylerinin iş performanslarının artmasında etkili bir faktör olduğu sonucuna ulaşılmıştır (Urgan, 2020). Boz ve arkadaşları (2019) vicdani zekâ ile iş performansı arasında anlamlı ilişkiler bulmuşlardır. Literatür tarandığında sağlık alanında mültecilere yönelik yabancı düşmanlığı tutumu ve vicdani zekâ özellikleri arasındaki ilişkinin incelendiği bir çalışmaya rastlanmamıştır. Bu araştırma alandaki boşluğu doldurarak sağlık hizmeti sunumunda mültecilere yaklaşım ve iletişim konusunda yeni bir bakış açısı kazandıracaktır.

$\mathrm{Bu}$ çalışma mültecilerle öğrencilik dönemlerinden itibaren klinik uygulamalarında karşılaşarak onlara sunulan sağlık hizmetlerinde görev alan ebelik öğrencileri ile yürütülmüştür. Çalışma ebelik öğrencilerinin göçmenlere/mültecilere yönelik yabancı düşmanlığı tutumları, bazı değişkenlerin etkisi ve vicdani zekâ özellikleri arasındaki ilişkinin belirlenmesi amacıyla yapılmıştır. Amaç doğrultusunda aşağıdaki sorulara cevap aranmıştır:

1. Ebelik öğrencilerinin yabancı düşmanlığg (zenofobi) tutumları ne düzeydedir?

2. Ebelik öğrencilerinin yabancı düşmanlığı düzeyleri çeşitli değişkenlerin (cinsiyet, öğrenim görülen birim, sınıf düzeyi, algılanan gelir düzeyi, göç ile ilgili eğitim alma durumu, üniversiteye gelmeden önce yaşanılan yerleşim yeri) etkisi var mıdır?

3. Öğrencilerin vicdani zekâ düzeyleri nasıldır?

4. Öğrencilerin zenofobik tutumları ve vicdani zekâ özellikleri arasındaki ilişki nedir?

\section{Materyal ve Yöntemler}

\subsection{Araştırmanın Türü, Evren ve Örneklem}

Bu çalışma, tanımlayıcı ve kesitsel tipte (15 Nisan-15 Mayıs 2021), Türkiye’de bir üniversitenin Sağlık Bilimleri Fakültesi Ebelik Bölümünde öğrenim görmekte olan öğrencileri ile gerçekleştirilmiştir. Çalışmanın evrenini, Türkiye'de, Orta Karadeniz bölgesinde bir Sağlık Bilimleri Fakültesi Ebelik Bölümünde okuyan öğrenciler $(\mathrm{N}=368)$ oluşturmuştur. Araştırmanın örneklemi için evreni bilinen örneklem hesabına gidilmiş ve \%90 güven aralığı ve \pm 5 sapma değeri ile 190 ebelik öğrencisi alınması gerektiği hesaplanmıştır. Araştırma gönüllü olarak katılmayı kabul eden 218 öğrenci ile tamamlanmıştır.

\subsection{Veri Toplama Araçları}

Çalışmada veri toplama aracı olarak; ebelik bölümü öğrencilerinin tanımlayıcı özelliklerini belirlemeye yönelik anket formu, Vicdani Zekâ Ölçeği (VZÖ) ve Yabancı Düşmanlığı (Zenofobi Ölçeği-ZÖ) kullanılmıştır. VZÖ ve ZÖ’nün kullanımı için yazarlardan elektronik posta yoluyla izin alınmıştır.

Kişisel bilgi formu: Araştırmacılar tarafından ilgili literatür (Urgan, 2020; Boz ve ark., 2019; Turan, 2018; Şengül ve Bulut, 2020) taranarak oluşturulan soru formu katılımcıların sosyo-demografik özelliklerini belirlemeye yönelik 12 sorudan oluşmaktadır.

Zenofobi Ölçeği (ZÖ)(Yabancı Düşmanlı̆̆ı): Bozdağ ve Kocatürk (2017) tarafından geliştirilen Yabancı Düşmanlığı Ölçeği, bireylerin göçmenlere yönelik tutumlarını, göçmen korkularını ölçmek amacıyla geliştirilmiş üç alt boyuttan oluşan (nefret, korku ve aşağılama), 18 maddeden oluşan (7. ve 11. maddeler ters kodlu) beşli likert tipte bir ölçektir. Ölçekte "Kesinlikle Katılmıyorum (1)" ile "Kesinlikle Katılıyorum (5)" arasında değişen puanlama derecesi kullanılmıştır. Ölçeğin Cronbach Alfa güvenirlik katsayısı 0.86'dır. Ölçekten alınabilecek en düşük puan 18, en yüksek puan ise 90 olup; ölçekten alınan puanlar arttıkça zenofobik (yabancı düşmanlığı) tutum düzeyi artmaktadır (Bozdağ ve Kocatürk, 2017). Bu çalışmada ölçeğin Cronbach Alfa katsayısı 0.89 'dur.

Vicdani Zekâ Ölçeği (VZÖ): Aktı ve ark. (2017) tarafından geliştirilen Vicdani Zekâ Ölçeği 5'li likert tipinde 32 maddeden $(1,2,3,4$ ve 5. sorular ters kodlu) oluşmaktadır. Ölçek, etik değerler, ahlâki duyarlılık, yaratıcıya karşı sorumluluk, merhamet, bilinçli farkındalık, toplumsal duyarlılık ve bilgelik olmak üzere yedi alt boyuttan oluşmaktadır. Ölçekte hiç Katılmıyorum'dan (1), Tamamen Katılıyoruma (5) değişen bir puanlama derecesi kullanılmıştır. Ölçeğin Cronbach alfa katsayısı 0.85 olarak 
bulunmuştur. Bu ölçekten alınabilecek en düşük puan 32 iken en yüksek puan 160'tır. Ölçekten alınan puan arttıkça vicdani zekâ düzeyinin arttığı gözlenmektedir. Bu çalışmada ölçeğin Cronbach alfa katsayısı 0.94’tür.

\subsection{Verilerin Toplanması}

Pandemi süreci nedeniyle, verilerin toplanması için Ebelik Bölümü öğrencilerine Google Forms üzerinden hazırlanan online anketler iletilmiş ve veriler 15 Nisan-15 Mayıs 2021 tarih aralığında toplanmıştır. Anket formlarını doldurma işlemi yaklaşık olarak 8-10 dakika sürmüştür.

\subsection{Verilerin Analizi}

Veriler bilgisayarda uygun paket program kullanılarak değerlendirilmiştir. Sayısal verilerin analizinde sayı, yüzde ve ortalamalar kullanılmıştır. Verilerin normal dağılıma uygunluğu Kolmogorov-Smirnov testi ile analiz edilmiş normal dağılım göstermeyen değişkenler için grup karşılaştırmalarında Mann-Whitney U testi uygulanmıştır. Değişkenler arasındaki korelasyon Spearman Korelasyon testi ile incelenmiştir. Kategorik değişkenlerin analizinde Kruskal Wallis testi kullanılmıştır. Elde edilen sonuçlar verilerin dağılımı +/-1 aralığında tespit edilmiştir. Büyüköztürk (2007) bu değerlerin +/-1 aralığında yer almasının normallikten aşırı sapmalar olmaması şeklinde yorumlamaktadır. İstatistiksel anlamlılık düzeyi p<0,05 olarak kabul edilmiştir.

\subsection{Araştırmanın Etik Yönü}

Çalışma öncesinde ölçek izinleri ve Tokat Gaziosmanpaşa Üniversitesi Sosyal ve Beşeri Bilimler Araştırma Etik Kurulu'ndan 02.04.21 tarihli 01-29 karar sayısı ile etik onay alınmıştır. Kurum araştırma uygulama izni alınmıştır. Öğrenciler Google online form üzerinden çalışmanın amacı hakkında bilgilendirilmiş ve çalışmaya katılmayı gönüllü olarak kabul ettiklerine dair seçeneği işaretlemelerinin ardından çalışmaya katılmışlardır.

\subsection{Araştırmanın Sınırlılıkları}

Araştırmanın olası sınırlılıkları; örneklem hacmi içerisinde veri toplanan öğrenci grubunun, 1. ve 2. sınıflarının meslek etiği dersini almamış olması, pandemi nedeni ile henüz klinik uygulama deneyimlerinin az olması, bir sağlıçı olma özelliği ile insanı değerlendirebilme becerisi henüz yeterli gelişmemiş ve dolayısı ile yabancı düşmanlığı ile vicdani zekâ değerlerini etkilemiş olabilir. Ayrıca bu konu hakkında daha önceden yapılan araştırmaların bulunmaması online geribildirim yöntemi ile elde edilen veriler olması gibi nedenlerle elde edilen veriler tüm ebelik öğrencilerine genellenemez.

\section{Bulgular}

Öğrencilerin yaş ortalaması 20.78 \pm 1.38 ( $\min =18, \max =27)$ yıldır. Çalışmamıza katılan öğrencilerin \%33.5’i ebelik bölümü 1 . sınıfta öğrenim görmektedir. Öğrencilerin \%74.8'i ebelik mesleğini isteyerek seçtiğini belirtmişlerdir. Öğrencilerin Ebelik mesleğini seçme nedenleri sorgulandığında \%54.1'i maddi nedenler sebebiyle seçtiğini ve öğrencilerin \%55'i ailesinde ya da yakın çevresinde ebe bir tanıdığının olmadığını ifade etmişlerdir. Öğrencilerin \%52.8'i ebelikte meslek etiği dersi aldığını kültürlerarası ebelikle ilgili bilgi almadığını (\%52.8) ve klinik uygulamalar sırasında en az bir kez mülteci kadınlara sağlık hizmeti sunduğunu (\%56) belirtmişlerdir. Mülteci kadınlara sağlık hizmeti sunan öğrencilerin sunduğu sağlık hizmetinin yeri sorgulandığında; öğrencilerin \%39.3'ü kadın hastalıkları servisi, \%38.5'i doğumhane, \%17.2'si kadın hastalıkları servisi ve doğumhane şeklinde yanıt vermişlerdir. Mülteci kadınlara sağlık hizmeti sunarken öğrencilerin en çok zorlandıkları konuları, öğrencilerin \%91.8'i iletişim, \%8.2'si kültürel farklılıklar olarak bildirmişlerdir (Tablo 1).

Tablo 1. Öğrencilerin tanıtıcı özellikleri ve mültecilere hizmet sunma durumlarına göre dağılımı (n=218)

\begin{tabular}{|c|c|c|}
\hline Özellikler & $\mathbf{n}$ & $\%$ \\
\hline $\begin{array}{l}\text { Sinıf } \\
\text { 1.sinıf } \\
\text { 2.sinıf } \\
\text { 3.sinıf } \\
\text { 4.sinıf }\end{array}$ & $\begin{array}{l}73 \\
30 \\
62 \\
53\end{array}$ & $\begin{array}{l}33.5 \\
13.8 \\
28.4 \\
24.3 \\
\end{array}$ \\
\hline $\begin{array}{c}\text { Ebelik mesleğini isteyerek seçme durumu } \\
\text { Evet } \\
\text { Hayır }\end{array}$ & $\begin{array}{c}163 \\
55 \\
\end{array}$ & $\begin{array}{l}74.8 \\
25.2 \\
\end{array}$ \\
\hline $\begin{array}{c}\text { Ebelik mesleğini seçme nedeni } \\
\text { Maddi nedenler } \\
\text { Manevi nedenler } \\
\text { Hem maddi hem manevi nedenler }\end{array}$ & $\begin{array}{l}118 \\
69 \\
15\end{array}$ & $\begin{array}{l}54.1 \\
31.7 \\
7.3\end{array}$ \\
\hline
\end{tabular}




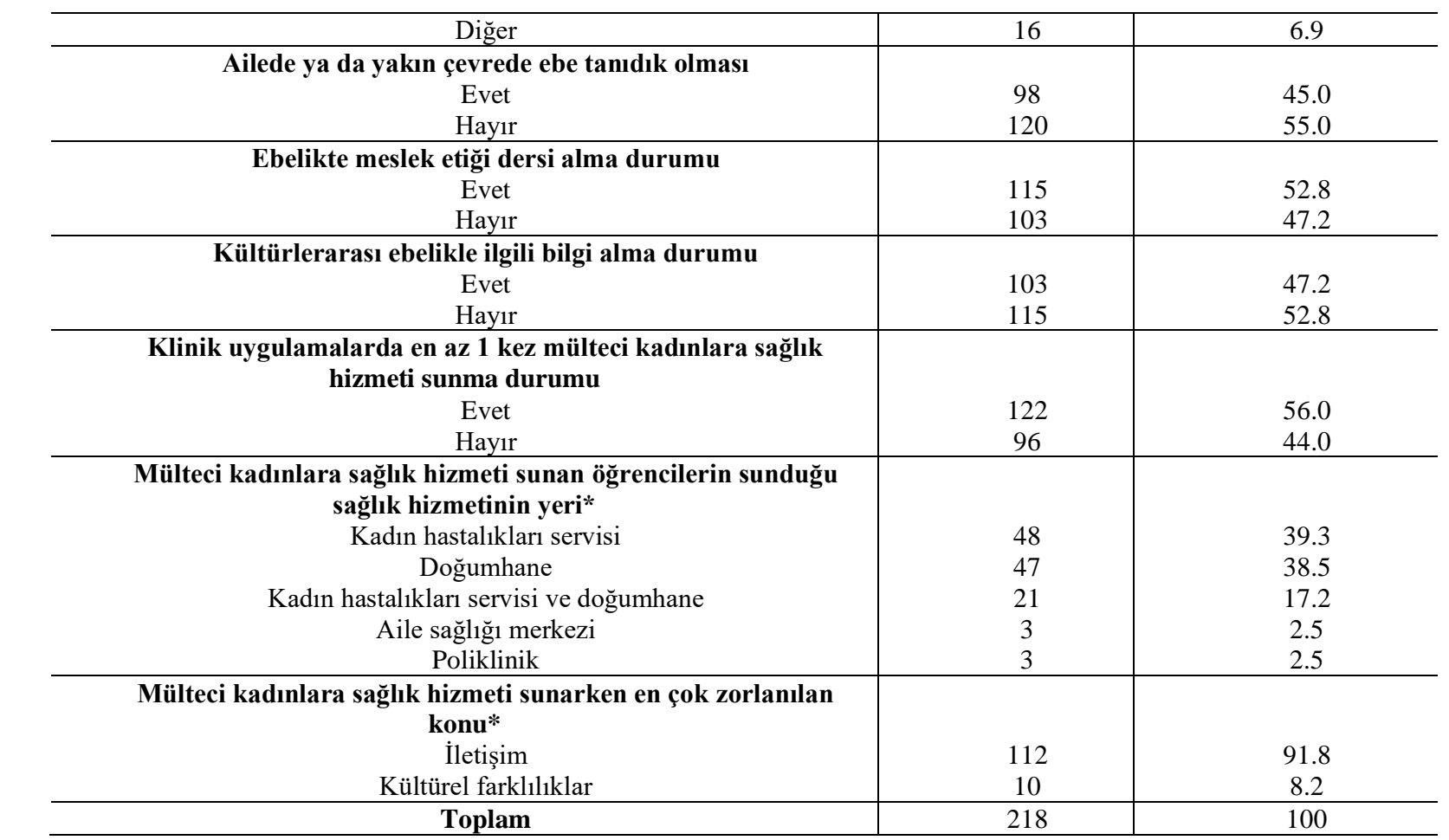

*:n=122 öğrenci üzerinden hesaplama yapılmıştır.

Tablo 2'de Öğrencilerin ZÖ toplam puan ortalaması $46.93 \pm 11.47$ ( $\min =20$, max=90) olarak bulunmuştur. ZÖ toplam puanlarına göre öğrencilerin yabancı düşmanlığı puan düzeylerinin düşük düzeyde olduğu söylenebilir. ZÖ nefret alt boyutu puan ortalamas1 $16.55 \pm 4.51(\min =7, \max =35)$, korku alt boyutu puan ortalaması $21.05 \pm 5.11$ ( $\min =8$, max=35), aşağ 1 lama alt boyutu puan ortalaması 9.31 $\pm 3.46(\min =4, \max =20)$ 'dır. Öğrencilerin VZÖ toplam puan ortalamas1 $125.44 \pm 15.41(\min =48, \max =157)$ olarak bulunmuştur. VZÖ etik değerler alt boyutu puan ortalaması $11.04 \pm 3.71(\mathrm{~min}=5$, max=24), ahlaki duyarlılık alt boyutu puan ortalaması $21.76 \pm 3.35(\mathrm{~min}=8, \max =25)$, yaratıcıya karşı sorumluluk alt boyutu puan ortalamas1 $16.26 \pm 2.63(\mathrm{~min}=7, \max =20)$, merhamet alt boyutu puan ortalaması $22.24 \pm 3.33(\mathrm{~min}=5, \max =25)$, bilinçli farkındalık alt boyutu puan ortalaması $20.66 \pm 3.35$ $(\min =6, \max =25)$, toplumsal duyarlılık alt boyutu puan ortalamas1 $16.68 \pm 2.69(\mathrm{~min}=7$, $\max =20)$ ve bilgelik alt boyutu puan ortalamasi $16.77 \pm 2.73(\min =4$, $\max =20)$ 'tür (Tablo 2$)$.

Tablo 2. Öğrencilerin Zenofobi Ölçeği ve Vicdani Zeka Ölçeği toplam puan ortalamaları

\begin{tabular}{|c|c|c|}
\hline \multicolumn{2}{|c|}{ Ölçekler ve Alt Boyutları } & $\mathrm{X}^{*} \pm \mathrm{SS}$ ( min-max) \\
\hline \multirow{4}{*}{ Zenofobi Ölçeği } & Toplam Puan & $46.93 \pm 11.47(20-90)$ \\
\hline & Nefret alt boyutu & $16.55 \pm 4.51(7-35)$ \\
\hline & Korku alt boyutu & $21.05 \pm 5.11(8-35)$ \\
\hline & Aşağılama alt boyutu & $9.31 \pm 3.46(4-20)$ \\
\hline \multirow{8}{*}{ Vicdani Zeka Ölçeği } & Toplam Puan & $125.44 \pm 15.41(48-157)$ \\
\hline & Etik değerler alt boyutu & $11.04 \pm 3.71(5-24)$ \\
\hline & Ahlaki duyarlılık alt boyutu & $21.76 \pm 3.35(8-25)$ \\
\hline & $\begin{array}{l}\text { Yaratıcıya karşı sorumluluk } \\
\text { alt boyutu }\end{array}$ & $16.26 \pm 2.63(7-20)$ \\
\hline & Merhamet alt boyutu & $22.24 \pm 3.33(5-25)$ \\
\hline & Bilinçli farkındalık alt boyutu & $20.66 \pm 3.35(6-25)$ \\
\hline & Toplumsal duyarlılık alt boyutu & $16.68 \pm 2.69(7-20)$ \\
\hline & Bilgelik alt boyutu & $16.77 \pm 2.73(4-20)$ \\
\hline
\end{tabular}

$* \mathrm{X}=$ Ortalama

Çalışmaya katılan öğrencilerin bazı tanıtıcı özelliklerine göre ZÖ ve VZÖ toplam puanları arasındaki ilişki Tablo 3’te verilmiştir. Öğrencilerin sınıfları ve ZÖ toplam puanları arasında istatistiksel olarak anlamlı düzeyde fark bulunmuştur. Yapılan post-hoc analizinde farkın kaynağına bakıldığında; farkın 1-4., 1-2., ve 1-3. sınıflar arasında olduğu tespit edilmiştir.

Öğrencilerin ebelik mesleğini isteyerek seçme durumları ve ZÖ toplam puanları arasında istatistiksel olarak anlamlı düzeyde bir fark bulunmuştur. Gruplar arasında ebelik bölümünü isteyerek seçmeyen grup lehine istatistiksel açıdan $p<0,05$ düzeyinde anlamlı bir farklılık saptanmıştır. Öğrencilerin ebelikte meslek etiği dersi alma ve ZÖ toplam puanları arasında dersi alanlar lehine istatistiksel olarak anlamlı düzeyde fark bulunmuştur. Öğrencilerin kültürlerarası ebelikle ilgili bilgi alma durumları ve ZÖ toplam 
puanları arasında istatistiksel olarak anlamlı düzeyde fark bulunmuştur. Gruplar arasında kültürlerarası ebelikle ilgili bilgi alan grup lehine istatistiksel açıdan $\mathrm{p}<0,05$ düzeyinde anlamlı bir farklılık saptanmıştır.

Öğrencilerin klinik uygulamalarda en az 1 kez mülteci kadınlara sağlık hizmeti sunma durumları ve ZÖ toplam puanları arasında istatistiksel olarak anlamlı düzeyde fark bulunmuştur. Gruplar arasında klinik uygulamalarda en az 1 kez mülteci kadınlara sağlık hizmeti sunan grup lehine istatistiksel açıdan $\mathrm{p}<0,05$ düzeyinde anlamlı bir farklılık saptanmıştır.

Öğrencilerin mülteci kadınlara sağlık hizmeti sunduğu yer ve ZÖ toplam puanları arasında istatistiksel olarak fark saptanmamıştır. Öğrencilerin mülteci kadınlara sağlık hizmeti sunarken en çok zorlandıkları konu ve ZÖ toplam puanları arasında istatistiksel olarak fark saptanmamıştır. Öğrencilerin VZÖ toplam puanları ve Tablo 3'te verilen tanıtıcı özellikleri arasında istatistiksel olarak anlamlı fark bulunamamıştır (Tablo 3).

Ölçekler arasındaki ilişkiyi belirlemek amacıyla yapılan korelasyon analizi sonucunda, ZÖ ile VZÖ toplam puanı arasında anlamlı bir ilişki bulunmamıştır ( $\mathrm{r}=\mathrm{p}>0.05)$ (Tablo4). ZÖ ile VZÖ alt boyutları arasındaki ilişki Tablo 4'te verilmiştir. Buna göre ZÖ toplam puanı ile VZÖ etik değerler alt boyutu puanı arasında pozitif yönde zayıf $(r=.144, p=0.034)$, ZÖ toplam puanı ile VZÖ merhamet alt boyutu arasında negatif yönde zayıf $(\mathrm{r}=-.191, \mathrm{p}=0.005)$ ilişki saptanmıştır. VZÖ toplam puanı ile ZÖ nefret alt boyutu arasında negatif yönde zayıf düzeyde ilişki bulunmuştur $(\mathrm{r}=-.172, \mathrm{p}=0.011)$. ZÖ nefret alt boyutu ile VZÖ etik değerler alt boyutu arasında pozitif yönde zayıf düzeyde $(\mathrm{r}=.157, \mathrm{p}=0.020)$, ahlaki duyarlılık $(\mathrm{r}=-.164, \mathrm{p}=0.015)$, merhamet $(\mathrm{r}=-.285$, $\mathrm{p}=0.000)$, toplumsal duyarlılık $(\mathrm{r}=-.192, \mathrm{p}=0.004)$ ve bilgelik $(\mathrm{r}=-.188, \mathrm{p}=0.005)$ alt boyutları arasında negatif yönde zayıf düzeyde bir ilişki saptanmıştır. Ayrıca ZÖ aşağılama alt boyutu ile VZÖ etik değerler alt boyutu arasında pozitif yönde zayıf düzeyde (r=.201, $\mathrm{p}=0.003)$, merhamet alt boyutu arasında negatif yönde zayıf düzeyde ( $\mathrm{r}=.153, \mathrm{p}=0.024)$ ilişki olduğu görülmüştür (Tablo 4).

Tablo 3. Öğrencilerin bazı tanıtıcı özelliklerine göre Zenofobi Ölçeği ve Vicdani Zekâ Ölçeği toplam puan ortalamalarının karşılaştırılması

\begin{tabular}{|c|c|c|c|c|}
\hline Özellikler & $\begin{array}{l}\text { ZÖ Toplam } \\
\text { Puan }\end{array}$ & Test Değeri & $\begin{array}{l}\text { VZÖ Toplam } \\
\text { Puan }\end{array}$ & Test Değeri \\
\hline $\begin{array}{l}\text { Sinıf } \\
\text { 1. } \text { sinif } \\
\text { 2. sinif } \\
\text { 3. sinif } \\
\text { 4. } \text { sinif }\end{array}$ & $\begin{array}{c}42.38 \pm 10.93 \\
50.26 \pm 13.80 \\
49.56 \pm 9.57 \\
48.22 \pm 11.17 \\
\end{array}$ & $\begin{array}{c}K W=20.565 \\
p=0.000\end{array}$ & $\begin{array}{l}126.32 \pm 15,71 \\
120.73 \pm 17,87 \\
124.27 \pm 16,43 \\
128.28 \pm 11,44 \\
\end{array}$ & $\begin{array}{c}\mathrm{KW}=4.267 \\
\mathrm{p}=0.234\end{array}$ \\
\hline $\begin{array}{c}\text { Ebelik mesleğini isteyerek } \\
\text { seçme } \\
\text { Evet } \\
\text { Hayır }\end{array}$ & $\begin{array}{l}46.09 \pm 11.83 \\
49.41 \pm 10.04\end{array}$ & $\begin{array}{c}Z=-2.690 \\
p=0.007\end{array}$ & $\begin{array}{l}125.42 \pm 15,32 \\
125.50 \pm 15,83\end{array}$ & $\begin{array}{c}Z=-0.040 \\
p=0.968\end{array}$ \\
\hline $\begin{array}{c}\text { Ailede ya da yakın çevrede } \\
\text { ebe tanıdık olması } \\
\text { Evet } \\
\text { Hayır }\end{array}$ & $\begin{array}{l}46.84 \pm 12.06 \\
47.00 \pm 11.01\end{array}$ & $\begin{array}{c}Z=-0.465 \\
p=0.642\end{array}$ & $\begin{array}{l}126.97 \pm 14,32 \\
124.20 \pm 16,20\end{array}$ & $\begin{array}{c}\mathrm{Z}=-1.313 \\
\mathrm{p}=0.189\end{array}$ \\
\hline $\begin{array}{c}\text { Ebelikte meslek etiği dersi } \\
\text { alma } \\
\text { Dersi alan } \\
\text { Dersi almayan }\end{array}$ & $\begin{array}{l}48.94 \pm 10.31 \\
44.67 \pm 12.31\end{array}$ & $\begin{array}{c}\mathrm{Z}=-\mathbf{3 . 2 7 3} \\
\mathrm{p}=\mathbf{0 . 0 0 1}\end{array}$ & $\begin{array}{l}126.12 \pm 14,43 \\
124.69 \pm 16,48\end{array}$ & $\begin{aligned} Z & =-0.438 \\
P & =0.661\end{aligned}$ \\
\hline $\begin{array}{c}\text { Kültürlerarası ebelikle ilgili } \\
\text { bilgi alma durumu } \\
\text { Evet } \\
\text { Hayır }\end{array}$ & $\begin{array}{l}49.07 \pm 11.67 \\
45.00 \pm 10.99\end{array}$ & $\begin{array}{l}Z=-2.654 \\
P=0.008\end{array}$ & $\begin{array}{l}126.10 \pm 15,26 \\
124.86 \pm 15,59\end{array}$ & $\begin{aligned} Z & =-0.635 \\
P & =0.526\end{aligned}$ \\
\hline $\begin{array}{c}\text { Klinik uygulamalarda en az } \\
1 \text { kez mülteci kadınlara sağlık } \\
\text { hizmeti sunma durumu } \\
\text { Evet } \\
\text { Hayır }\end{array}$ & $\begin{array}{l}48.32 \pm 11.34 \\
45.15 \pm 11.45\end{array}$ & $\begin{array}{l}Z=-2.190 \\
P=0.028\end{array}$ & $\begin{array}{l}126.63 \pm 14,84 \\
123.94 \pm 16,06\end{array}$ & $\begin{array}{l}Z=-1.465 \\
P=0.143\end{array}$ \\
\hline $\begin{array}{c}\text { Mülteci kadınlara sağlık } \\
\text { hizmeti sunan öğrencilerin } \\
\text { sunduğu sağlık hizmetinin yeri* } \\
\text { Kadın hastalıkları servisi } \\
\text { Doğumhane } \\
\text { Kadın hastalıkları servisi ve } \\
\text { doğumhane } \\
\text { Aile sağlığı merkezi } \\
\text { Poliklinik }\end{array}$ & $\begin{array}{c}47.47 \pm 10.92 \\
48.29 \pm 10.12 \\
48.19 \pm 12.13 \\
55.33 \pm 2.30 \\
56.33 \pm 30.98\end{array}$ & $\begin{array}{c}\mathrm{KW}=3.288 \\
\mathrm{P}=0.511\end{array}$ & $\begin{array}{r}124.16 \pm 17,78 \\
129.38 \pm 12,73 \\
125.09 \pm 11,26 \\
128.66 \pm 18,55 \\
131.66 \pm 12,74\end{array}$ & $\begin{array}{c}\mathrm{KW}=3.660 \\
\mathrm{P}=0.454\end{array}$ \\
\hline $\begin{array}{c}\text { Mülteci kadınlara sağlık } \\
\text { hizmeti sunarken en çok } \\
\text { zorlanılan konu* } \\
\text { İletişim }\end{array}$ & $48.79 \pm 11.16$ & $Z=-1.859$ & $126.51 \pm 15,23$ & $Z=-1.055$ \\
\hline
\end{tabular}




\begin{tabular}{c|c|c|c|c}
\hline Kültürel farkl1lıklar & $41.60 \pm 11.25$ & $\mathrm{P}=0.063$ & $120.60 \pm 18,08$ & $\mathrm{P}=0.291$ \\
\hline
\end{tabular}

KW: Kruskal Wallis Testi,U: Mann-Whitney U Testi

Tablo 4. Zenofobi Ölçeği ve Vicdani Zekâ Ölçeği arasındaki korelasyon

\begin{tabular}{|c|c|c|c|c|c|c|}
\hline & & & \multicolumn{4}{|c|}{ Zenofobi Ölçeği } \\
\hline & & & Toplam & $\begin{array}{l}\text { Nefret alt } \\
\text { boyutu }\end{array}$ & $\begin{array}{l}\text { Korku alt } \\
\text { boyutu }\end{array}$ & $\begin{array}{l}\text { Așağılama } \\
\text { alt boyutu }\end{array}$ \\
\hline \multirow{8}{*}{ 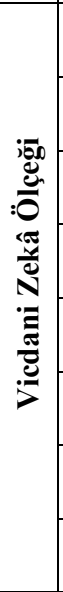 } & Toplam & $\begin{array}{l}\mathrm{r}_{\mathrm{s}} \\
\mathrm{p}\end{array}$ & $\begin{array}{l}-.072 \\
0.289\end{array}$ & $\begin{array}{l}-.172 * \\
0.011\end{array}$ & $\begin{array}{c}.010 \\
0.887\end{array}$ & $\begin{array}{l}-.026 \\
0.697\end{array}$ \\
\hline & Etik değerler alt boyutu & $\begin{array}{l}\mathrm{r}_{\mathrm{s}} \\
\mathrm{p}\end{array}$ & $\begin{array}{l}.144 * \\
0.034\end{array}$ & $\begin{array}{l}.157 * \\
0.020\end{array}$ & $\begin{array}{c}.079 \\
0.247\end{array}$ & $\begin{array}{l}.201 * * \\
0.003\end{array}$ \\
\hline & $\begin{array}{l}\text { Ahlaki duyarlılık alt } \\
\text { boyutu }\end{array}$ & $\begin{array}{l}\mathrm{r}_{\mathrm{s}} \\
\mathrm{p}\end{array}$ & $\begin{array}{l}-.039 \\
0.563 \\
\end{array}$ & $\begin{array}{l}-.164 * \\
0.015\end{array}$ & $\begin{array}{c}.060 \\
0.378 \\
\end{array}$ & $\begin{array}{l}-.063 \\
0.352 \\
\end{array}$ \\
\hline & $\begin{array}{c}\text { Yaratıcıya karşı } \\
\text { sorumluluk alt boyutu }\end{array}$ & $\begin{array}{l}\mathrm{r}_{\mathrm{s}} \\
\mathrm{p}\end{array}$ & $\begin{array}{l}-.055 \\
0.421\end{array}$ & $\begin{array}{l}-.127 \\
0.061\end{array}$ & $\begin{array}{c}.014 \\
0.833 \\
\end{array}$ & $\begin{array}{l}-.020 \\
0.771\end{array}$ \\
\hline & Merhamet alt boyutu & $\begin{array}{l}\mathrm{r}_{\mathrm{s}} \\
\mathrm{p}\end{array}$ & $\begin{array}{c}-.191 * * \\
0.005\end{array}$ & $\begin{array}{c}-.285 * * \\
0.000\end{array}$ & $\begin{array}{l}-.074 \\
0.279\end{array}$ & $\begin{array}{l}-.153 * \\
0.024\end{array}$ \\
\hline & $\begin{array}{l}\text { Bilinçli farkındalık alt } \\
\text { boyutu }\end{array}$ & $\begin{array}{l}\mathrm{r}_{\mathrm{s}} \\
\mathrm{p}\end{array}$ & $\begin{array}{l}-.019 \\
0.777\end{array}$ & $\begin{array}{l}-.071 \\
0.298\end{array}$ & $\begin{array}{c}.014 \\
0.837\end{array}$ & $\begin{array}{c}.006 \\
0.932\end{array}$ \\
\hline & $\begin{array}{c}\text { Toplumsal duyarlılık alt } \\
\text { boyutu }\end{array}$ & $\begin{array}{l}\mathrm{r}_{\mathrm{s}} \\
\mathrm{p}\end{array}$ & $\begin{array}{l}-.106 \\
0.119 \\
\end{array}$ & $\begin{array}{l}-.192 * * \\
0.004 \\
\end{array}$ & $\begin{array}{l}-.033 \\
0.627 \\
\end{array}$ & $\begin{array}{l}-.060 \\
0.381 \\
\end{array}$ \\
\hline & Bilgelik alt boyutu & $\begin{array}{l}\mathrm{r}_{\mathrm{s}} \\
\mathrm{p}\end{array}$ & $\begin{array}{l}-.115 \\
0.092\end{array}$ & $\begin{array}{l}-.188 * * \\
0.005\end{array}$ & $\begin{array}{l}-.008 \\
0.904\end{array}$ & $\begin{array}{l}-.120 \\
0.076\end{array}$ \\
\hline
\end{tabular}

$* \mathrm{p}<0,05 ; * * \mathrm{p}<0,01 ; \mathrm{r}_{\mathrm{s}}$ : Spearman korelasyon katsay1s1

\section{Tartışma}

Ebelik öğrencilerinin mültecilere yönelik zenofobik tutumları, vicdani zekâ puanlarına bazı sosyo-demografik etkenlerin etkisi ve ölçek puanları arasındaki ilişkinin değerlendirilmesi amacıyla yapılan çalışmada; öğrencilerin göçmen korkularının orta düzeyin altında olduğu; nefret, korku ve aşağılama alt boyutlarından alınan puanların ortalamanın altında olduğu belirlenmiştir. Bir sağlık okulundaki öğrencilerin zenofobik tutumlarının ortalamanın altında olmasının gelecekte verilecek hizmet, bakımın kalite ve memnuniyetini artırmaya, daha insancıl, ayrım yapmadan bakım sağlamaya katkı sağlayacağı düşünülmektedir ve bu önemlidir. Sağlık okulu öğrencileri ile yapılmış çalışma bulunmamakta ancak, üniversite öğrencileri ile yapılan bir çalışmada öğrencilerin zenofobi düzeylerinin düşük olduğu belirtilmiştir (Bozdağ, 2020). Literatürde diğer çalışmalarda da üniversite öğrencilerinin zenofobi düzeylerinin düşük olduğu, çalışmamızın sonuçları ile benzer olduğu söylenebilir (Kayitesi ve Mwaba, 2014; Coetzee,2012).

Çalışmamızda sosyo-demografik değişkenlerden mesleğini sevmeden seçenlerin zenofobi puanlarının anlamlı derecede daha yüksek olduğu, bu durumunda etik dersi almış olsa dahi göçmenle klinikte karşılaşanlarda da olumsuz etki yaratarak anlamlı derecede diğer öğrencilere oranla daha fazla zenofobik tutum sergiledikleri gözlenmiştir. Bunu nedenlerinden birinin etik duyarlılıkları düşük olan öğrencilerde zenofobik tutumun artması olarak gösterilebilir.

Araştırmamızda öğrencilerin dörtte üçü ebelik mesleğini isteyerek seçmiştir. Bizim çalışmamıza benzer biçimde Dinç ve arkadaşları (2017), yaptıkları çalışmada öğrencilerin dörtte üçünün bölümü isteyerek tercih ettiğini belirlemiştir. Başka bir çalışmada ise ebelik bölümü öğrencilerinin neredeyse yarısının mesleği isteyerek tercih ettiğini belirlemişlerdir (Ay ve ark., 2018). $\mathrm{Bu}$ çalışmaların aksine bazı araştırmalarda ebelik mesleğinin adaylar tarafından yeterince tanınmadan seçildiğini, meslek seçimini iş bulma ve ekonomik olarak getirisinin daha fazla olması, insana duyulan ilgi, aile ve yakınlarının isteği, okul giriş puanının düşük olması gibi nedenlerle, çoğunluğunun mesleği istemeden seçtiği saptanmıştır (Bilgi Ocakçı, 2011). Çalışma hayatında başarılı olmasının ve doyuma ulaşmasının; adayın mesleğe girerken taşıdığı güdülere bağlı olduğu ve motivasyonun öğrencinin kendisinden gelmesi gerektiği belirtilmektedir. Mesleği severek ya da isteyerek seçmek hizmet verecek gruba yönelik olumlu davranış sergilemede her zaman etkili olmuştur (Tuzcuoğlu, 1994). Bu nedenle bizim çalışmamızda da meslek tercihinin özellikle zenofobik tutumu etkilediği $(\mathrm{p}<0.05)$ görülmektedir. Çalışmamızda öğrencilerin ebelik mesleğini isteyerek seçme durumları ile ZÖ toplam puanları arasında istatistiksel düzeyde anlamlı fark bulunmuştur.

Katılımcıların vicdani zekâ puanları, öğrenim gördükleri sınıf, ebelik mesleğini isteyerek seçme, ailede tanıdık ebe olması, ebelik meslek etik dersi alması, kültürlerarası ebelikle ilgili bilgi alma durumları, klinik uygulamalarda en az 1 kez mülteci kadınlara sağlık hizmeti sunma, mesleği isteyerek seçme karşılaştırıldığında aralarında fark olmadığı belirlenmiştir. Genel olarak ebelik öğrencilerinin toplamda $125.44 \pm 15.41$ puan alarak oldukça yüksek vicdani bir zekaya sahip oldukları; ahlaki değerler, yaratıcıya karşı sorumluluk alt boyutlarında istatistiksel olarak anlamlı bir farklılığa rastlanmazken; etik değerler boyutunda orta, merhamet, bilinçli farkındalık, toplumsal duyarlılık, bilgelik alt boyutlarında ise ortanın oldukça üzerinde puana sahip oldukları tespit edilmiştir. Genel olarak ebelik öğrencilerinin kadın cinsiyette olmasının (Şengül ve Bulut, 2020), ebelik eğitimi öğretilerinin 
olumlu etkilerinin buna neden olduğu, öğrencilerin daha vicdani zekaya; merhamet, bilinçli farkındalık, toplumsal duyarlılık, bilgelik gibi özelliklere sahip oldukları söylenebilir (Tarhan, 2015). Vicdani zekanın bireyin sorumluluklarının farkında olması ve iç bilinç düzeyi ile ilişskili hareket bileşimleri olarak tanımlandığı dikkate alınırsa, öğrencilerin vicdanî değerlerden hareket etmekte daha iyi olabilecekleri söylenebilir. Bu yetenekleri ile de öğrenciler daha iyi düzeyde bildiklerini yeni problemlerin çözümünde kullanma, mantıklı akıl yürütme, sosyal ve kültürel çevreye uyum için kararlar alma özelliklerine sahipler denilebilir (Akgündüz, 2001).

Araştırmamızda öğrencileri 3. sınıfa geldiklerinde müfredatları gereği hem meslek etiği derslerini hem de doğum gibi meslek derslerini almakta ve klinik uygulamalara yoğun biçimde çıkmaktadırlar. Öğrencilerin ZÖ toplam puanları ile ebelikte meslek etiği dersi alma ile benzer biçimde üst sınıflarda olmaları, kültürlerarası ebelikle ilgili bilgi alma durumları, klinik uygulamalarda en az 1 kez mülteci kadınlara sağlık hizmeti sunma, mesleği isteyerek seçme karşılaştırıldığında, derslerin içeriğinde insan ayrımı yapılmaması ve etik ilkelerle ilgili çok fazla konu işlemelerine rağmen öğrencilerin zenofobik tutum sergiledikleri istatistiksel olarak anlamlı biçimde farklı bulunmuştur. Ebelikte meslek etiği dersi müfredat gereği meslek mensubu bireylere temel meslek etik değerlerinin kazandırıldığı bir derstir. Bu derse rağmen bazı ebelik öğrencilerinde eğitimde kazandırılmaya çalışılan adalet, eşitlik, karşımızdaki insanı bir insan olarak tanımak, onu anlamak ve onun tarafından anlaşılmak gibi değerlerin kazandırılmasının, "yabancı düşmanlığı, vatandaş olmayan gruplara yabancı kökenleri ya da uyrukları temel alınarak olumsuz algı ve uygulamalardan oluşan ayrımcılık" (Crush ve Ramachandran, 2009) tutumunu engelleyemediği görülmektedir. Yine bu durum öğrencilerin yaklaşı üçte birlik kısmının mesleğini isteyerek seçmemesinden etkilenmiş olabilir.

Çalışmaya katılan öğrencilerin mevcut bulundukları sınıfları ve ZÖ toplam puanları arasında yine istatistiksel olarak anlamlı düzeyde fark bulunmuştur. Yapılan post-hoc analizinde farkın kaynağına bakıldığında; 1-4., 1-2., ve 1-3. sınıflar arasında olduğu tespit edilmiştir. Bu fark üçüncü ve dördüncü sınıf öğrencilerindedir mesleki deneyimlerini diğer öğrencilere göre daha fazla olmasına rağmen yabancı uyrukları temel alarak olumsuz algı ve uygulamalardan oluşan ayrımcılık tutumlarının olması düşündürücüdür. Psikolojide kullanılan fobi kelimesi, akla yatkın ve somut bir nedene dayanmaksızın kişinin kaygı düzeyinin yükselmesi anlamına geldiği için, yabancı korkusu yaşanmış herhangi bir deneyime dayanmadan ortaya çıkabilmektedir. Süreci başlatan bu durum sonucunda korkulan şeyden hoşlanmama, tedirginlik, nefret, öfke, tiksinme gibi duygular ortaya çıkmakta ve düşmanca tavır alma düzeyine varabilmektedir (Akgündüz, 2001). Öğrencilerin deneyimli olmasının ZÖ tutumunu azaltmaya etkisinin olmaması bu nedenlerden kaynaklanmış olabilir.

Şengül ve Bulut, (2020) araştırmalarında vicdani zekâ alt toplam puanları ile katılımcıların öğrenim gördükleri sınıf değişkenine göre gruplar arası ve gruplar içi farkı istatistiksel olarak anlamlı bulunmuşlardır. Bir başka araştırmada katılımcıların öğrenim gördükleri sınıf değişkenine göre vicdani zekâ düzeyleri incelendiğinde; ahlaki değerler, yaratıcıya karşı sorumluluk alt boyutlarında istatistiksel olarak anlamlı bir farklılığa rastlanmazken; etik değerler, merhamet, bilinçli farkındalık, toplumsal duyarlılık, bilgelik alt boyutlarında istatistiksel olarak anlamlı farklılık tespit edilmiştir (Turan, 2018). Araştırmamızda bu bulguların aksine vicdani zekâ ölçeğinden alınan puanlar ile sınıf değişkeni arasında anlamlı bir ilişki bulunmamıştır. Korelasyon analizi ile vicdani zeka puanı ve zenofobik tutum arasındaki ilişki değerlendirilmiş ve aralarında anlamlı bir ilişki bulunmamıştır $(\mathrm{r}=\mathrm{p}>0.05)$.

Vicdani zekanın da öğrencilerin zenofobik tutumlarına etkisinin olmadığı, sadece pozitif yönde bir ilişki olduğu belirlenmiştir. Vicdani zekâ etik alt boyutuna bakıldığında puan artıkça etik duyarlılığın azaldığı dolayısı ile öğrencilerin daha fazla zenofobik tutum sergiledikleri ve aralarında zayıf yönde bir ilişki olduğu söylenebilir ( $r=.144, p=0.034)$. İncinebilir grupta olan mültecilerin karşılaştığ fiziksel zorlukların yanı sıra zenofobik tutum onların daha dezavantajlı hale getirmektedir. Ancak öğrencilerin etik duyarlılı̆̆ arttıkça daha az zenofobik tutuma sahip olmaları sevindirici ve önemli bir bulgudur.

Yine ZÖ toplam puanı ile VZÖ merhamet alt boyutu arasında negatif zayıf yönde bir ilişki olduğu, burada merhameti yüksek olan öğrencilerin daha azalan biçimde zenofobik tutum sergiledikleri bu tutumunda sevindirici olduğu söylenebilir. Öğrencilerin VZÖ toplam puanı ve ahlaki duyarlılık, merhamet, toplumsal duyarlılık ve bilgelik alt boyutu ile ZÖ nefret, aşağılama alt boyutu arasında, negatif yönde zayıf düzeyde ilişki bulunmuştur. Nefret duygularının vicdani zeka arttıkça azalıyor olması önemli bir bulgudur, ebelik öğrencilerinin genel VZÖ puanının yüksekliği düşünülünce daha yüksek ahlaki duyarlılık, merhamet, toplumsal duyarlılık ve bilgelik duygularının yabancı düşmanlığı, nefretin azaltacağını söylemek olasıdır. Sağlık çalışanları bireylerin en zor, en özel, en sıkıntılı anlarında yanlarında olan ve onlara sağlık hizmeti sunan meslek grubudur. Dezavantajlı gruba bakım verirken ebelik öğrencilerinin daha duyarlı yaklaşılmasını sağlayacaktır.

Birçok uluslararası kuruluş, merhametin ebelik bakımının merkezinde ve gebelik, doğum ve doğum sonrası dönemlerde kadınlara, bebeklere ve ailelere yetenekli, bilgili ve şefkatli bakım sağlayan bir profesyonel olduğunu belirtmiştir (Ergin ve ark., 2020). Çalışmamızda ZÖ aşağılama alt boyutu ile VZÖ’nin etik değerler, ahlaki duyarlılık alt boyutu arasında pozitif yönde zayıf düzeyde, merhamet alt boyutu arasında ise negatif yönde zayıf düzeyde bir ilişki olduğu belirlenmiştir. Ebelik öğrencilerini de literatürde belirtildiği gibi profesyonelliğe adım atarken eğitimleri gereği, etik değerler, ahlaki duyarlılıkları ve merhamet arttıkça yabancı düşmanlığı/korkusunun azalmasının görülmesi oldukça önemlidir. 


\section{Sonuç ve Öneriler}

Çalışmada Ebelik öğrencilerinin göçmen korkularının orta düzeyin altında olduğu, vicdani zeka puanlarının oldukça yüksek olduğu, mesleğini sevmeyerek seçenlerde zenofobi puanlarının diğer öğrencilere göre daha yüksek olduğu saptanmıştır. Vicdani zekâ bireyin eylemlerini yerine getirirken bir denetleme mekanizması oluşturarak insan davranışlarını organize eder. Bu duruma sağlık profesyonelleri açısından bakıldığı zaman bireylerin ihtiyaçlarına daha duyarlı yaklaşmalarını sağlar. Özellikle incinebilir gruplara sağlık hizmeti sunarken bu durum daha da ön plana çıkmaktadır.

Mültecilere primer sağlık hizmeti sunan grupta yer alan ebelere öğrencilik dönemlerinden itibaren bu konuda eğitimler verilerek, kültürlerarası ebelik dersinin yaygınlaştırılarak zenofobik tutumun daha da azaltılması hedeflenebilir. Ebelik meslek etiği dersinin içeriği düzenlenerek kültürlerarası ebelik konusunun eklenmesi önerilebilir. Ayrıca bu konuda farklı örneklemlerde çalışılması önerilir.

\section{Çıkar Çatışması}

Yazarlar çıkar çatışması olmadığını beyan ederler.

\section{Teşekkür}

Araştırmaya katılımlarından dolayı Ebelik Bölümü öğrencilerine teşekkürlerimizi sunarız. Bu çalışma 5. Uluslararası 6 Ulusal Ebelik Kongresi'nde sözel bildiri olarak sunulmuştur.

\section{Referanslar}

[1] Akgündüz,A. (2001). Dahinin El Kitabı, Genç Beyin Yayınları, İstanbul,s:13.

[2] Aktı, Ü., Giderler, C., Duran, C., Behdioğlu, S., \& Boz, D. (2017). Vicdani zekâ ölçeği: geçerlilik ve güvenirlik çalışması. İslam Medeniyeti Araştırmaları Dergisi, 2(3), 329-349.

[3] Ay, F., Keçe, M., İnci, İ., Alkan, N., \& Acar G. (2018). Ebelik öğrencilerinin meslek algıları ve kariyer planlarını etkileyen faktörler. Balıkesir Sağlık Bilimleri Dergisi, 7(2), 74-82.

[4] Bilgin, Z, Ocakçı, A.F. (2011): Ebelik Öğrencilerinde Mesleki Güdülenme. Anadolu Hemşirelik ve Sağl1k Bilimleri Dergisi; 14(3):40-46

[5] Boz, D, Duran, C. ve Narin İ. (2019). Vicdanî Zekânın İş Performansı İle İlişkisi: kamuda örnek bir uygulama. Dursun Boz (Ed.), Vicdanî zekâ iş performansı içinde, s.69-97, Ankara: Gece Akademi.

[6] Bozdağ, F., \& Kocatürk, M. (2017). Zenofobi Ölçeği'nin Geliştirilmesi: Geçerlik Ve Güvenirlik Çalışmaları. Journal of International Social Research, 10(52), 615-20

[7] Bozdağ, F., Üniversite öğrencilerinin zenofobi düzeyleri, INTE, ISTEC, IETC, ITICAM \& IWSC - 2020 at Faculty of Education, Cyprus International University, Nicosia, TRNC.

[8] Büyüköztürk, Ş. (2007). Sosyal Bilimler İçin Veri El Kitabı, İstatistik, Araştırma Deseni, SPSS Uygulamaları ve Yorum. Ankara: Pegem yayınc1lık.

[9] Coetzee, E. (2012). Emploring perceptions of xenophobia in a sample of South African employees. Journal of Psychology in Africa, 22(4), 609-620. https://doi.org/10.1080/14330237.2012.10820575

[10] Crush, J., Ramachandran, S. (2009). Xenophobia, International Migration and Human Development (rep., 1-104). New York: United Nations Development Programme. Human Development Reports, Research Paper.

[11] Dinç., A., Cangöl, E., \& Sögüt, S. (2017). Ebelik öğrencilerinin mesleki tercih hakkında düşünceleri. Cumhuriyet Üniversitesi Sağlık Bilimleri Enstitüsü Dergisi, 2(2), 15-23.

[12] Ergin, A., Özcan, M., Aksoy, S. D. (2020). Doğum odasında çalışan ebelerin şefkat düzeyleri. Hemşirelik Etiği, 27(3), 887-898.

[13] Gümüş, Y. Bilgili N. (2015). Göçün Sağlık Üzerindeki Etkileri. Anadolu Hemşirelik ve Sağlık Bilimleri Dergisi, 18(1). 
[14] International Labour Office (2001). International migration, racism, discrimination and xenophobia. https://publications.iom.int/system/files/pdf/international_migration_racism.pdf Erişim tarihi 04.05.2021

[15] İmamoğlu, A. (2010). Vicdan kavramının psiko-sosyal tahlili. Akademik İncelemeler Dergisi, 5(1), 127-144.

[16] Kayitesi, M. \& Mwaba, K. (2014). South African university students' life satisfaction and perceptions of African immigrants. Social Behaviour and Personality, 42(7), 1127-1132. https://doi.org/10.2224/sbp.2014.42.7.1127

[17] Miller, E., Decker, M. R., Silverman, J. G., \& Raj, A. (2007). Migration, sexual exploitation, and women's health: a case report from a community health center. Violence Against Women, 13(5), 486-497.

[18] Suleman, S., Garber, K. D., \&Rutkow, L. (2018). Xenophobia as a determinant of health: an integrativereview. Journal of publichealthpolicy, 39(4), 407-423.

[19] Şengül, H. \& Bulut, A. (2020). Bir vakıf üniversitesinin sağlık bilimleri fakültesinde okuyan öğrencilerin vicdani zeka seviyelerinin analizi. Turkish Studies-Social, 15(6), 3131-3148. https://dx.doi.org/10.47356/TurkishStudies.44332

[20] Tarhan, N. (2015). Mesnevi Terapi, Timaş Yayınları, 11. Baskı, İstanbul.

[21] Turan, M.B. (2018) Beden eğitimi ve spor yüksekokulu öğrencilerinin vicdani zeka düzeylerinin bazı değişkenlere göre incelenmesi. Türk Spor Bilimleri Dergisi, 1(2), 78-88.

[22] Tuzcuoğlu S. (1994). “Meslek Seçimi ve Önemi”. M.Ü. Atatürk Eğitim Fakültesi Eğitim Bilimleri Dergisi, 6:265-280

[23] United Nations High Commissioner for Refugees (UNHCR) (2019). The Global Report Forced Displacement In 2019. https://www.unhcr.org/5ee200e37/ erişim tarihi. 07.05.2021

[24] United Nations High Commissioner for Refugees (UNHCR) (1967). Convention And Protocol Relating To The Status Of Refugees. https://www.unhcr.org/3b66c2aa10 erişim tarihi. 07.05.2021

[25] Urgan, S., Gönüllü Hizmetlerde Vicdanî Zekânın Yaşam Tatmini Ve İş Performansına Etkisi: Eskişehir Akut Örneği, BMIJ, (2020), 8(3): 2727-2749, doi: http://dx.doi.org/10.15295/bmij.v8i3.1543

[26] Yakushko, O. (2009). Xenophobia: Understanding the roots and consequences of negative attitudes toward immigrants. The Counseling Psychologist, 37(1), 36-66. 